\title{
CXCR3-binding Chemokines: Novel Multifunctional Therapeutic Targets
}

\author{
E. Lazzeri and P. Romagnani*
}

\author{
Department of Clinical Pathophysiology, University of Florence, Viale Pieraccini 6, 50139-Firenze, Italy
}

\begin{abstract}
The goal to attenuate inflammation without inducing generalized immunosuppression has focused the attention on chemokines, a family of chemotactic peptides that regulate the leukocyte traffick into tissues. However, the development of drugs that block ckemokine activity may be hampered by the observation that some chemokines display pleiotropic biologic functions. For example, the chemokines CXCL9/Mig, CXCL10/IP-10, and CXCL11/I-TAC exhibit the ability to recruit different leukocytes subsets, the capacity to induce the proliferation of vascular pericytes as well as powerful anti-tumor effects, which are mediated by a common receptor, named CXCR3. Because of their pleiotropic biologic effects, these chemokines have been proposed as possible therapeutic targets in cancer, allograft rejection, glomerulonephritis, diabetes, multiple sclerosis, and autoimmune disorders of the thyroid. The chemokine CXCL4/PF4 shares several activities with CXCL9, CXCL10, and CXCL11, including angiostatic effects, although its specific receptor has remained unknown for a long time. Recently, we provided evidence that the different functions of CXCL9, CXCL10, and CXCL11 on distinct cell types can be at least partly explained by the interaction of these chemokines with two distinct receptors. Indeed, in addition to the classic form of CXCR3 receptor, which we have renamed as CXCR3-A, a novel CXCR3 receptor variant (CXCR3-B) was identified, that not only mediates the angiostatic activity of CXCR3 ligands, but also acts as functional receptor for CXCL4.

In this review, we focus on the accumulating evidence demonstrating the pivotal role of CXCR3-binding chemokines in several human diseases. Studies based on CXCR3 targeting have shown its importance in different pathologic conditions and orally active small molecules capable of inhibiting this receptor are now being developed in order to be tested for their activity in humans.
\end{abstract}

Key Words: Angiogenesis, inflammation, transplantation, tumor, glomerulonephritis, thyroid, diabetes.

\section{INTRODUCTION}

Chemokines are a family of small, structurally related, molecules that regulate cell trafficking of various subsets of leukocytes [1-3] and are distinguishable from other cytokines because they are the only members of the cytokine family that act on the superfamily of G-protein-coupled serpentine receptors. Even though these properties still define their nature, other important functions of chemokines have been discovered, including regulation of embryonic development [4], pathophysiology of the central nervous system [5], wound healing repair [6], control of angiogenesis [7] and tumor growth and spread [8]. The nomenclature for chemokines is based on the configuration of a conserved amino-proximal cysteine-containing motif. Based on this system, there are currently four groups of molecules in the chemokine family: $\mathrm{CXC}, \mathrm{CC}, \mathrm{CX}_{3} \mathrm{C}$, and $\mathrm{C}$ (where $\mathrm{X}$ is any amino acid). Chemokines were initially named according to their function or on the basis of the cell type that produced them, giving rise to redundant names for the same chemokine sequence. In order to eliminate such a confusion, a systematic nomenclature has recently been adopted (Table 1) $[1]$.

\footnotetext{
*Address correspondence to this author at the Department of Clinical Pathophysiology, University of Florence, Viale Pieraccini 6, 50139-Firenze Italy; Tel: ++390554271483; Fax: ++390554271371;

E-mail: p.romagnani@dfc.unifi.it
}

\section{CXCR3-BINDING CHEMOKINES EXHIBIT UNIQUE, PLEIOTROPIC BIOLOGIC FUNCTIONS}

The CXC chemokine subfamily includes fourteen different members, whose encoding genes are clustered on human chromosome 4, with the exception of SDF1/CXCL12, which is mapped to 10q11.21, BRAK/CXCL14, which is mapped to 5q31.1, and CXCL16, which is mapped to $17 \mathrm{q} 13$. [5]. Most members of the CXC chemokine family exhibit chemotactic properties toward neutrophils and lymphocytes, and act as positive or negative regulators of angiogenesis. The angiostatic members of the CXC chemokine family include IP-10/CXCL10, MIG/CXCL9, ITAC/CXCL11 and PF-4/CXCL4 [3-7]. These chemokines induce injury on established tumor-associated vasculature and promote extensive tumor necrosis [3-7] and, therefore, they have been proposed as useful therapeutic agents in cancer [4]. The angiostatic effects of CXCL9, CXCL10, and CXCL11 on human microvascular endothelial cells (HMVEC) are mediated by the CXC chemokine receptor 3 (CXCR3) [9, 10], whereas the receptor for CXCL4 has remained unknown for a long time [4]. Several studies have pointed out that CXCL10 and CXCL4 share a great number of activities, such as the inhibition of chemotaxis and the proliferation of endothelial cells [11], or the inhibition of hematopoiesis [12]. However, the interaction of CXCL9, CXCL10, and CXCL11 with CXCR3 also results in the chemotaxis of activated type-1 T helper (Th1) cells, natural killer (NK) cells, macrophages, and dendritic cells [13-17], 
Table 1. List of all known Chemokines, their Specific Receptors and Chromosome Localization.

\begin{tabular}{|c|c|c|c|}
\hline $\begin{array}{c}\text { CHEMOKINE } \\
\text { (new nomenclature) }\end{array}$ & CHROMOSOME & $\begin{array}{c}\text { CHEMOKINE } \\
\text { (old nomenclature) }\end{array}$ & RECEPTOR \\
\hline \multicolumn{4}{|c|}{ CXC CHEMOKINES } \\
\hline CXCL1 & $4 q 12-q 13$ & GRO- $\alpha$ & CXCR2>CXCR1 \\
\hline CXCL2 & $4 q 12-q 13$ & GRO- $\beta$ & CXCR2 \\
\hline CXCL3 & $4 q 12-q 13$ & GRO- $\gamma$ & CXCR2 \\
\hline CXCL4 & $4 \mathrm{q} 12-\mathrm{q} 13$ & PF4 & CXCR3 - B $\gg>>C X C R 3-A$ \\
\hline CXCL5 & $4 \mathrm{q} 12-\mathrm{ql} 3$ & ENA-78 & CXCR2 \\
\hline CXCL6 & $4 q 12-q 13$ & GCP-2 & $\mathrm{CXCRl/CXCR2}$ \\
\hline CXCL7 & $4 q 12-q 13$ & NAP-2 & CXCR2 \\
\hline CXCL8 & $4 \mathrm{q} 12-\mathrm{q} 13$ & IL.-8 & CXCR1, CXCR2 \\
\hline CXCL9 & $4 \mathrm{q} 21.21$ & Mig & CXCR3-A/CXCR3-B \\
\hline CXCL10 & $4 \mathrm{q} 21.21$ & IP-10 & CXCR3-A/CXCR3-B \\
\hline CXCL11 & $4 \mathrm{q} 21.21$ & I-TAC & CXCR3-A/CXCR3-B \\
\hline CXCL12 & $10 \mathrm{q} 11.1$ & SDF-l $\alpha / \beta$ & CXCR4 \\
\hline CXCL13 & $4 \mathrm{q} 21$ & BLC/BCA-1 & CXCR5 \\
\hline CXCL14 & $5 q 31.1$ & BRAK & unknown \\
\hline CXCL15 & unknown & Lungkina/WECHE & unknown \\
\hline CXCL16 & $17 \mathrm{ql3}$ & & CXCR6 \\
\hline \multicolumn{4}{|c|}{ C CHEMOKINES } \\
\hline XCL1 & $1 \mathrm{q} 23$ & Lymphotactin & $\mathrm{XCR} 1$ \\
\hline XCL2 & $1 \mathrm{q} 23$ & SCM-13 & XCR1 \\
\hline \multicolumn{4}{|c|}{ CX3C CHEMOKINES } \\
\hline CX3CL1 & $16 \mathrm{q} 13$ & Fractalkine & CX3CR1 \\
\hline \multicolumn{4}{|c|}{ CC CHEMOKINES } \\
\hline CCL1 & $17 \mathrm{q} 11.2$ & I-309 & CCR8 \\
\hline CCL2 & $17 \mathrm{q} 11.2$ & MCP-1 & CCR2, CCR11 \\
\hline CCL3 & $17 \mathrm{q} 11.2$ & MIP- $1 \alpha$ & CCR1, CCR5 \\
\hline CCL4 & $17 \mathrm{q} 11.2$ & MIP-1 $\beta$ & CCR5 \\
\hline CCL5 & $17 \mathrm{q} 11.2$ & RANTES & CCR1, CCR3, CCR5 \\
\hline CCL6 & unknown & C10/MRP-1 & unknown \\
\hline CCL7 & $17 \mathrm{q} 11.2$ & MCP-3 & CCR1, CCR2, CCR3, CCR11 \\
\hline CCL8 & $17 \mathrm{q} 11.2$ & MCP-2 & CCR3, CCR11 \\
\hline CCL9/10 & unknown & MIP- $1 \gamma$ & unknown \\
\hline CCL11 & $17 \mathrm{q} 11.2$ & eotaxin & $\mathrm{CCR} 3$ \\
\hline
\end{tabular}


(Table 1. Contd....)

\begin{tabular}{|c|c|c|c|}
\hline $\begin{array}{c}\text { CHEMOKINE } \\
\text { (new nomenclature) }\end{array}$ & CHROMOSOME & $\begin{array}{c}\text { CHEMOKINE } \\
\text { (old nomenclature) }\end{array}$ & RECEPTOR \\
\hline CCL12 & unknown & MCP-5 & $\mathrm{CCR} 2$ \\
\hline CCL13 & $17 \mathrm{q} 11.2$ & MCP-4 & CCR2, CCR3, CCR11 \\
\hline CCL14 & $17 \mathrm{q} 11.2$ & HCC-1 & CCR1 \\
\hline CCL15 & $17 \mathrm{q} 11.2$ & HCC-2 & CCR1, CCR3 \\
\hline CCL16 & $17 \mathrm{q} 11.2$ & LEC & CCR1, CCR8 \\
\hline CCL17 & $16 \mathrm{q} 13$ & TARC & CCR4 \\
\hline CCL18 & $17 \mathrm{q} 11.2$ & PARC & unknown \\
\hline CCL19 & $9 \mathrm{p} 13$ & ELC & CCR7, CCR10 \\
\hline CCL20 & $2 q 33-q 37$ & LARC & CCR6 \\
\hline CCL21 & $9 \mathrm{p} 13$ & SLC & CCR7, CCR10 \\
\hline CCL22 & $16 \mathrm{q} 13$ & MDC & CCR4 \\
\hline CCL23 & $17 \mathrm{q} 11.2$ & MPIF-1 & CCR1 \\
\hline CCL24 & $7 \mathrm{q} 11.23$ & eoTaxin-2 & CCR3 \\
\hline CCL25 & 19p13.2 & TECK & CCR9 \\
\hline CCL26 & $7 \mathrm{q} 11.23$ & eoTaxin-3 & CCR3 \\
\hline CCL27 & $9 \mathrm{p} 13$ & CTACK & CCR10 \\
\hline CCL28 & $5 \mathrm{p} 12$ & MEC & CCR3/CCR10 \\
\hline
\end{tabular}

while CXCL4 chemotactic properties are less pronounced and much more controversial [18,19]. Furthermore, CXCL9 and CXCL10 induce increased survival and growth of several types of human vascular pericytes recruitment their receptor CXCR3 [20-22]. Thus, the apparently opposite effects of CXCR3-binding chemokines on HMVEC and on vascular pericytes allowed us to hypothesize the existence of cell-specific signal transduction pathways and/or distinct CXCR3 receptor variants. Accordingly, recent results obtained in our laboratory [23] have identified a novel mRNA generated by an alternative splice site within the intron of the CXCR3 gene by using rapid amplification of cDNA ends (RACE) and Northern blot analysis. Real Time Quantitative RT-PCR and transfection of the HMVEC line HMEC-1 provided evidence for the existence of a previously unrecognized receptor, named CXCR3-B, which mediated the inhibitory activity of CXCL9, CXCL10, and CXCL11 on the growth of HMVEC. Binding assay and signal transduction analysis demonstrated that CXCR3-B also acts as a functional receptor for CXCL4, thus explaining the large overlap between the biological activities of CXCL10 and CXCL4 and their potent angiostatic effect. By contrast, the classic CXCR3 receptor, re-named as CXCR3-A, mediates the proliferation of vascular pericytes [23]. In this review, we will focus on the possible role of CXCR3-binding chemokines in those diseases for which many converging results are now available.

\section{CXCR3-BINDING CHEMOKINES IN CANCER BIOLOGY}

In the early 1990, CXCL10 was reported to elicit a hostmediated and $\mathrm{T}$ cell-dependent antitumor effect against a murine plasmacytoma and mammary adenocarcinoma [24]. Accordingly, CXCL9 and CXCL10 mediate chemotaxis of activated T cells, NK cells, dendritic cells and $\gamma \delta$ cells, thus targeting all the components of the anti-tumor immune response [13-17]. However, CXCL10 appears to exert antitumor effect also independently of $\mathrm{T}$ and B-cell immunity, because it was also active in SCID mice [25-27]. Although NK cells recruited by CXCL9 and CXCL10 can be responsible for tumor regression in SCID mice [28], CXCL10 induces injury on established tumor-associated vasculature with intravascular thrombosis and extensive tumor necrosis [25-27]. In a similar way, CXCL9-treated tumors displayed central and homogeneous necrosis, as one might expect from insufficient tumor blood perfusion, and generalized evidence of vascular damage [28,29]. Furthermore, CXCL10 expression by human lung tumors in SCID mice was associated with reduced tumor growth potential, while neutralization of CXCL10 enhances growth, and overexpression of CXCL9 resulted in the inhibition of non small cell lung cancer tumor growth and metastasis via a decrease in tumor-derived vessel density [28]. Many studies also support a critical role for CXCL10 and CXCL9 in 
mediating the antitumor effect of IL-12 [30-34]. Another chemokine exerting powerful anti-tumor properties in SCID mice models is CXCL4 [35-40]. CXCL4 displays antiangiogenic activity in vivo and can inhibit the growth of tumors without exerting relevant activity in the recruitment of inflammatory cells $[39,40]$. CXCL4 inhibits angiogenesis through different concomitant mechanisms. Because of their heparin-binding motifs, both CXCL4 and CXCL10 have been shown to interfere with the binding of fibroblast growth factor (FGF)-2 or vascular endothelial growth factor (VEGF)165 to their receptors (i) by imparing the growth factor's ability to form homodimers, (ii) competing with heparan sulfate proteoglycans on the cell surface, or (iii) directly binding to these growth factors [41,42]. However, a large body of evidence also indicates that CXCL4 could deliver its specific inhibitory signal through a not yet identified specific receptor that, like CXCR3-B [9], is expressed by HMVECs only when they proliferate [43-45]. The discovery of CXCR3-B as the first high affinity functional receptor for CXCL4, and as a common receptor for the four angiostatic chemokines shed a new light on this controversial problem. CXCL4 showed a strong anti-tumor activity in in vivo models of breast cancer, melanoma, colon carcinoma, osteosarcoma, ovarian cell carcinoma and glioma [35-40]. Some studies however, also proposed a concomitant direct inhibitory effect on the growth of carcinoma cells [46, $47,23]$.

\section{CXCR3-BINDING CHEMOKINES IN ENGRAFTMENT AND ALLOGRAFT SURVIVAL}

Despite the administration of immunosuppressants, allograft rejection remains the primary cause of human renal transplant failure. Acute rejection (AR) is particularly frequent in the early post-transplant period and, despite the graft loss in only a small percentage of subjects, it represents a leading cause of morbility and hospitalization, and predisposes renal allografts to the development of chronic rejection (CR) [48]. Cardiac allograft recipients lacking CXCR3 have a profound delay in development of allograft rejection [49]. Consistent with this study, targeting of CXCL10 production by endothelial cells from a transplant, which was demonstrated using cardiac grafts from CXCL 10 donors [50], also remarkably prolonged graft survival. A concomitant treatment with a subtherapeutic dose of cyclosporine A (CsA), led to permanent allograft survival in $\mathrm{CXCR}^{-/-}$recipients [51]. Therapy with an anti-CXCR3 mAb can prevent graft recruitment of activated $\mathrm{T}$ cells and reverse the development of acute allograft rejection in rodent models [49]. The value of targeting donor-derived CXCL10 production was also shown in a heterotopic small bowel allograft model [51]. Hence, local upregulation of CXCL10 lead to the initial activation of $\mathrm{CXCR} 3^{+} \mathrm{NK}$ cells and release of interferon (IFN)- $\gamma$ by these cells, followed by further upregulation of CXCL10 and production of additional chemokines. The allo-response is then progressively amplified through the recruitment of $\mathrm{CXCR}^{+}{ }^{+} \mathrm{T}$ helper (Th)1 cells and other effector cells, especially macrophages. In contrast to blocking monoclonal antibodies (mAbs), antisense therapy directed at CXCR3 [52], or blockade of chemokine binding to local glycosaminoglycans [53], has proven to be modestly effective. There is now a rapidly developing literature on the expression of chemokines and their receptors in human allografts [54]. Of relevance, the intragraft expression of CXCR3 and its ligands has been reported in association with clinical rejection of renal [55], lung [56], and cardiac [57-60] allografts. In the unique on renal allograft study, induction of CXCR3 and CXCL10 mRNA was associated with acute rejection [56]. In the considerably larger lung study [57], immunohistological analyses showed that areas characterized by acute cellular rejection (grades 1-4) and active obliterative bronchiolitis (chronic rejection) were infiltrated by $\mathrm{CXCR}^{+} \mathrm{T}$ cells, and high levels of CXCR3 ligands were found within bronchoalveolar lavage fluids of patients with rejection episodes. Furthermore, in 169 sequential endomyocardial biopsies from clinical cardiac allograft recipients [57], the expression of CXCR3 and its ligand CXCL10 was temporally and spatially associated with $\mathrm{CD}^{+} \mathrm{T}$ cell infiltrates, and correlated with the histopathological diagnosis of acute rejection. Persistent expression of $\mathrm{CD}^{+}$ and $\mathrm{CXCR}^{+}{ }^{+}$infiltrating cells was seen in biopsies from four out of seven patients followed for one year, who developed intimal thickening, as shown by intravascular ultrasound. Indeed, CXCR3 chemokines not only attract leukocytes, but also alter the functions of vascular wall cells [23]. The dual targets of CXCR3 chemokines on immune and vascular cells suggest an important role for this group of cytokines in chronic rejection and allograft arteriosclerosis, a disease characterized by immune-mediated vascular smooth muscle cell proliferation. Data linking intragraft expression of CXCR3 and its ligands with development of acute and chronic cardiac allograft rejection were recently also reported by other groups [57-59]. In addition, elevated levels of the CXCR3 ligand, CXCL11, were associated with the development of coronary artery transplant vasculopathy [60], whereas serum levels of MCP-1/CCL2, although raised, were not [61]. A recent study provided the first direct evidence that persistent elevation of CXCL10 and CXCL11 in human cardiac allografts is associated with the development of chronic rejection. CXCR3 chemokines most likely recruit $\mathrm{T}$ cells to transplanted hearts, and also alter vascular EC and smooth muscle cell (SMC) functions. Both processes can promote the development of chronic allograft vasculopathy (CAV). Very recently, we demonstrated that CXCL10, CXCL9, CXCL11 and CXCL4, as well as both the receptor variants CXCR3-A and CXCR3-B, are highly expressed in the kidney of subjects suffering from either AR or CR (Lazzeri E. et al. submitted). As hypothesized, CXCR3-B was highly expressed by endothelial cells of damaged vascular structures, thus suggesting its contribution to EC necrosis. Surprisingly however, CXCR3-B was also widely expressed at level of tubular structures in both $A R$ and CR. The expression of CXCR3-B was also confirmed, at both mRNA and protein level, by primary cultures of renal proximal tubular epithelial cells. Surface expression of CXCR3-B was linked to the S-phase of the cell cycle and mediated growth inhibition of epithelial cells, suggesting that CXCR3-B expression might contribute not only to chronic EC injury, but also to interstitial damage and tubular atrophy during AR and CAN (Lazzeri E. et al. submitted). Finally, the demonstration that pretransplant serum CXCL10 levels in patients with end stage renal disease undergoing chronic 
dialytic treatment are a clinically useful parameter for the identification of subjects exhibiting high risk of graft failure (Rotondi M. et al. submitted) suggests that these subjects may require heavier postransplant immunosuppressive regimens.

\section{CXCR3-BINDING CHEMOKINES IN PROLIFERA- TIVE GLOMERULONEPHRITIS}

The proliferation of resident mesangial cells and the expansion of mesangial matrix, accompanied by elicitation of lymphocytes and monocytes from the circulation into the inflammed tissue, are prominent features of many types of immunologically mediated GN that, in agreement with these important pathologic alterations, are named proliferative glomerulonephritis (PGN). PGN are socially important diseases, inasmuch as $\operatorname{IgA}$ nephropathy is presently the most frequent kind of acute nephritis throughout the world [62].

Recent reports have focused attention on the relationship between inflammatory nephropaties and chemokines [63,64]. CXCL10 was found to be produced by mesangial cells (MC), and the kidney appears to be the most important source of this chemokine in response to IFN- $\gamma$ stimulation [65]. Recently, we have reported high expression of CXCL9 and CXCL10 by resident glomerular cells and of their receptor, CXCR3, in MC of patients with proliferative GN $[66,20]$. Moreover, CXCR3 was also found on the surface of cultured human MC (HMC), and appeared to mediate both intracellular $\mathrm{Ca}^{2+}$ influx and cell proliferation [20]. Furthermore, it was found that in both HMC and other types of vascular pericytes, CXCL10 and CXCL9 also induce chemotaxis and CXCR3 triggering results in Src activation, which in turn leads to the recruitment of Ras and activation of the ERK cascade [21]. In parallel, activation of PI 3-K and Akt can also be observed [21]. Taken all together, these findings may account for at least some mechanisms involved in the pathogenesis of proliferative GN. It is indeed reasonable to speculate that the initial event, such as deposition of immune complexes, interactions of $\operatorname{Ig} \mathrm{A}$ immunoglobulins with their Fc receptors expressed on HMC, or other insults, may induce both CXCL9 and CXCL10 production by resident glomerular cells [66], thus favoring the transmigration of Th1 cells and macrophages through the activation of adhesion molecules. Accordingly, Th1 effectors have been observed in the glomeruli of patients affected by severe proliferative $\mathrm{GN}$, as well as in the glomeruli of patients affected by active forms of $\operatorname{IgA}$ nephropathy [67]. Activated Th1 cells and macrophages are able to produce IFN- $\gamma$ and TNF- $\alpha$, which in turn can amplify both CXCL10 and CXCL9 production. Interestingly, the administration of IFN- $\gamma$ before the stimulation of mesangial cell (MC) with PDGF or EGF dramatically increases their proliferation, suggesting a possible pathogenic role of Th1 cells recruited by CXCL10 and CXCL9 glomerular expression in the early phase of proliferative GN [68]. Whether the same initial insult that induces CXCL10 and CXCL9 production and consequently the recruitment of Th1 cells and macrophages is also responsible for the up-regulation of CXCR3 expression by $\mathrm{MC}$ in the same kidneys is presently unclear. However, the interaction of CXCL10 and CXCL9 with their receptor expressed by $\mathrm{MC}$ can account for chronic stimulation of their proliferation and, therefore, the production of these chemokines allows to explain multiple aspects of the inflammatory reaction characteristic of proliferative GN.

\section{CXCR3-BINDING CHEMOKINES IN DIABETES}

Insulin-dependent (type 1) diabetes mellitus (IDDM) is a $\mathrm{T}$ cell-driven autoimmune disease of unknown etiology that results in the destruction of the islets of Langerhans in predisposed individuals. The mechanisms by which antigenspecific $T$ cells migrate to the islets - a prerequisite for the specific lysis of $\beta$ cells-is largely unknown. Given the absence of knowledge on the etiologic agent of IDDM, delineating the process of T-cell infiltration provides a basis for understanding the development of this autoimmune disease. A recent study demonstrated that during insulitis, the $\beta$ cell itself synthesizes and secretes CXCL9 and CXCL10, which are the driving force for the accumulation of the $\mathrm{CXCR}^{+}$cytotoxic T cells [69]. Thus, $\beta$ cells, the target of autoimmunity in IDDM, are largely responsible for attracting islet-specific cytotoxic $\mathrm{T}$ cells and thus facilitate their own demise. High IFN- $\gamma$ concentration in $\beta$ islets correlated with both substantial expression of CXCL9, CXCL10 and CXCR3 and prominent infiltration of T cells. IFN- $\gamma$ was necessary and sufficient to stimulate CXCL9 and CXCL10 expression in cells, as the selective exposure of these cells to IFN- $\gamma$ was sufficient to induce the expression of both chemokines. Taken together, these data suggest that the pathology of islet invasion represents an inflammatory loop effected by $\mathrm{T}$ cell-derived IFN- $\gamma$, which first induces CXCL10/CXCL9 in $\beta$ cells, leading to heightened immigration of additional IFN- $\gamma$-secreting $\mathrm{T}$ cells, that is in turn mediated by CXCR3 [69,70]. The significant role of CXCR3 in the immunopathogenesis of IDDM was directly demonstrated in a model of IDDM transgenic mice crossed with mice deficient for CXCR3. At day 8 after infection, islets of singly transgenic mice demonstrated severe T-cell infiltration and islet destruction. In contrast, the islets of transgenic CXCR3-deficient mice were not invaded, although $\mathrm{T}$ cells adorned their rim. In addition, monitoring blood glucose levels revealed a significant delay in the occurrence of diabetes in transgenic mice, which had been made deficient for CXCR3. These observations demonstrate the critical importance of CXCR3 over other inflammatory chemokine receptors in the pathogenesis of IDDM Fig. (1). Some data on the role of CXCL10 in the pathogenesis of IDDM are also available in human beings. IFN- $\gamma$ and CXCL10 were quantified by solid-phase ELISA in the sera of patients with either newly diagnosed or long-term IDDM, as well as in the sera of their healthy first degree relatives. The latter were subdivided into "low" and "high" risk prediabetic subjects, depending on whether they were negative or positive for the anti islet cell antibodies (ICA) and glutamic acid decarboxylase antibodies (GAD). Compared with healthy control subjects, those with a low risk of disease and the group of patients with long-term IDDM, CXCL10 was found more frequently and at increased concentrations in both newly diagnosed IDDM patients and in those with a high risk of disease; in the latter, the CXCL10 concentrations correlated with levels of IFN- $\gamma$ [71-73]. The results of these studies demonstrate that circulating CXCL10 


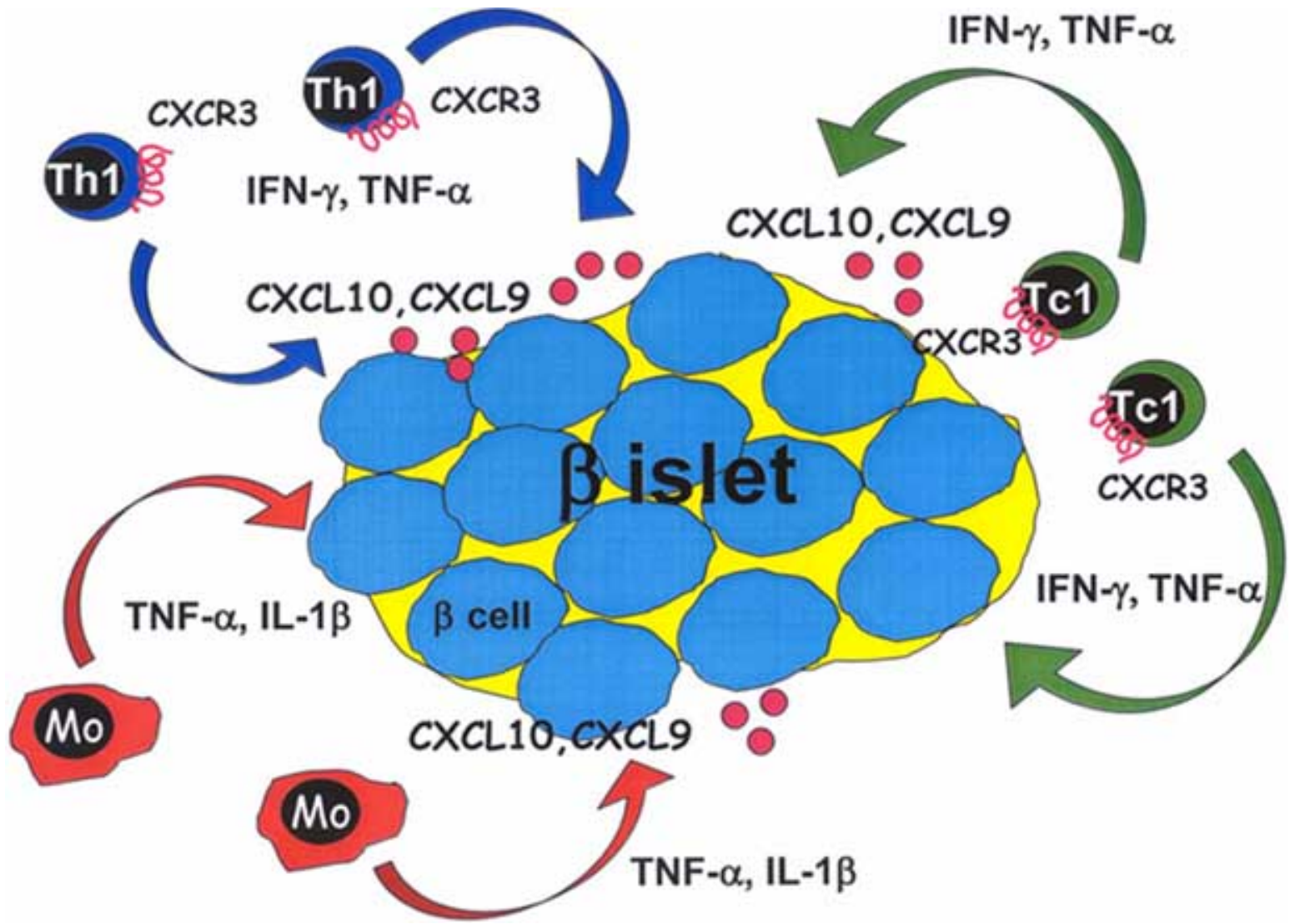

Fig. (1). Proposed mechanism of lymphocyte recruitment during the early phases of IDDM leading to insulitis and $\beta$-cell destruction. $\beta$ cells, the target of autoimmunity in IDDM, synthesize and secrete CXCL9 and CXCL10 and are largely responsible for attracting isletspecific $\mathrm{CXCR}^{+}$cytotoxic $\mathrm{T}$ cells, thus facilitating their own demise. The recruitment of Th1 cells and macrophages leads to amplification and persistence of the inflammatory response.

concentrations are increased in patients with IDDM, but only during the early and subclinical stage of the disease. However, given the large prevalence of female subjects in all these studies among the groups of newly diagnosed IDDM patients compared to controls, these results have been questioned. Indeed, in a recent study performed in a larger number of patients, where controls and newly diagnosed IDDM patients were exactly sex-matched, this observation was not confirmed, while higher CXCL10 levels were observed among female subjects when compared to males $[70,74]$. This finding might be related to the well known high prevalence among young women of subclinical autoimmune thyroid disorders, a condition that was associated with high CXCL10 serum levels even in patients groups containing comparable numbers of men and women $[70,75]$.

\section{CXCR3-BINDING CHEMOKINES IN MULTIPLE SCLEROSIS}

Multiple sclerosis (MS) is an autoimmune disease associated with a Th1 cell predominance phenotype. It is therefore believed that activated $\mathrm{T}$ cells have a crucial role. Chemokine receptors have been shown to be highly expressed in brain samples from MS patients after autopsy [76-78]. One of these receptors, CXCR3, is expressed by activated $\mathrm{T}$ cells, so it might be responsible for the recruitment of auto-aggressive T cells. This hypothesis was further supported by the demonstration of high levels of the CXCR3 ligand CXCL10 in these lesion samples. Cerebrospinal fluid (CSF) levels of CXCL9 and CXCL10 were significantly elevated in MS patients, and there was a positive correlation between the concentration of CXCL10 and CSF cell count. Other chemokines that act on monocytes

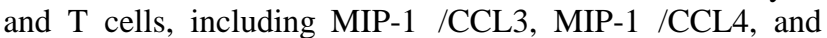
MCP-1/CCL2, were either undetectable or modestly reduced during MS attacks [78]. More importantly, CXCR3 was the predominant chemokine receptor on lymphocytic cells in both CSF and parenchymal compartments. These findings support the possibility that activated $\mathrm{T}$ cells expressing CXCR3 preferentially gain access to central nervous system (CNS) tissues during the formation of acute MS lesions. Accordingly, $80 \%$ of $\mathrm{CD}^{+}$cells in MS CSF expressed CXCR3, suggesting that these receptor-bearing cells play an important role in MS pathogenesis. The functional relevance of elevated CSF CXCL10 and CXCL9 levels in MS was further supported by the uniform detection of CXCR3positive cells in perivascular inflammatory cuffs in MS brain sections [76-78]. The accumulation of these cells was directly correlated with lesions in which demyelination occurs, followed by axonal loss, which ultimately leads to paralysis. These data are consistent with previous reports showing that anti-CXCL10 antibodies abolished chemotactic activity toward T-cell blasts in the CSF of patients with 
meningitis [79]. The demyelination process that occurs in the central nervous system (CNS) of patients with MS is due, in part, to an inflammatory response in which CD4+ and CD8+ $\mathrm{T}$ cells and macrophages infiltrate white matter. While it is thought that the inflammatory and demyelination process in MS is the product of Th1-associated cytokines secreted by myelin protein-specific CD4+ T cells present in the CNS, the mechanisms responsible for the recruitment and maintenance of these myelin-reactive CD4+ T cells in the CNS have not yet been elucidated. In a recent study, it was demonstrated that the majority of the chemotactic activity toward CD4+ T cells specific for a myelin basic protein peptide is mediated by CXCL10 [80] Fig. (2).

\section{CXCR3-BINDING CHEMOKINES IN AUTOIMMUNE THYROID DISORDERS}

Thyroid glands affected by autoimmune disorders show striking lymphocytic infiltration, mainly composed by $\mathrm{T}$ cells [81]. The mechanisms by which the different lymphocytic subsets are recruited and arrested in the thyroid tissue are unknown. Recent studies provided evidence that the chemokines CXCL10 and CXCL9, as well as their common receptor, CXCR3, are present in human tissue specimens obtained from patients affected by thyroid autoimmune disorders $[75,82,83]$. Thyroids from both patients with Graves' disease (GD) or Hashimoto's thyroidites (HT) expressed higher levels of CXCL10,
CXCL9 and CXCR3, if compared not only with normal thyroids, but also with toxic adenoma (TA), a nonautoimmune thyroid disorder $[75,82,83]$. Interestingly, as previously described in papillary carcinoma of the thyroid [84], resident epithelial follicular cells expressed CXCL10 and CXCL9 mRNA and protein, suggesting a possible role for the inflammed thyroid epithelium in the recruitment of infiltrating lymphocytes. Finally, a significant inverse correlation was observed between serum levels of CXCL10 and GD but not HT disease duration [75] .

Taken together, these data suggest a possible pathogenic role of chemokines CXCL10 and CXCL9 in the initiation of autoimmune thyroid disorders and provide additional evidence to the view that Th1-dominated responses, or at least the production of IFN- $\gamma$ and TNF- $\alpha$, may play an important pathogenic role in the initial events of the inflammatory process in these diseases $[75,82,83]$. On the other hand, the finding that CXCL10 production declines at level of both thyroid gland and serum in GD, but not in HT patients in the later phases of these disorders, may be consistent with the results of another study suggesting a progressive switch from Th1- to Th2-polarized profile in the course of GD but not in HT [85]. This shift probably reflects a counter regulatory mechanism against inflammation, which has been observed even in other diseases [86,87]. Previous studies [88] demonstrated that GD thyrocytes expressed CD95 and CD95L in a similar manner to HT thyrocytes, but

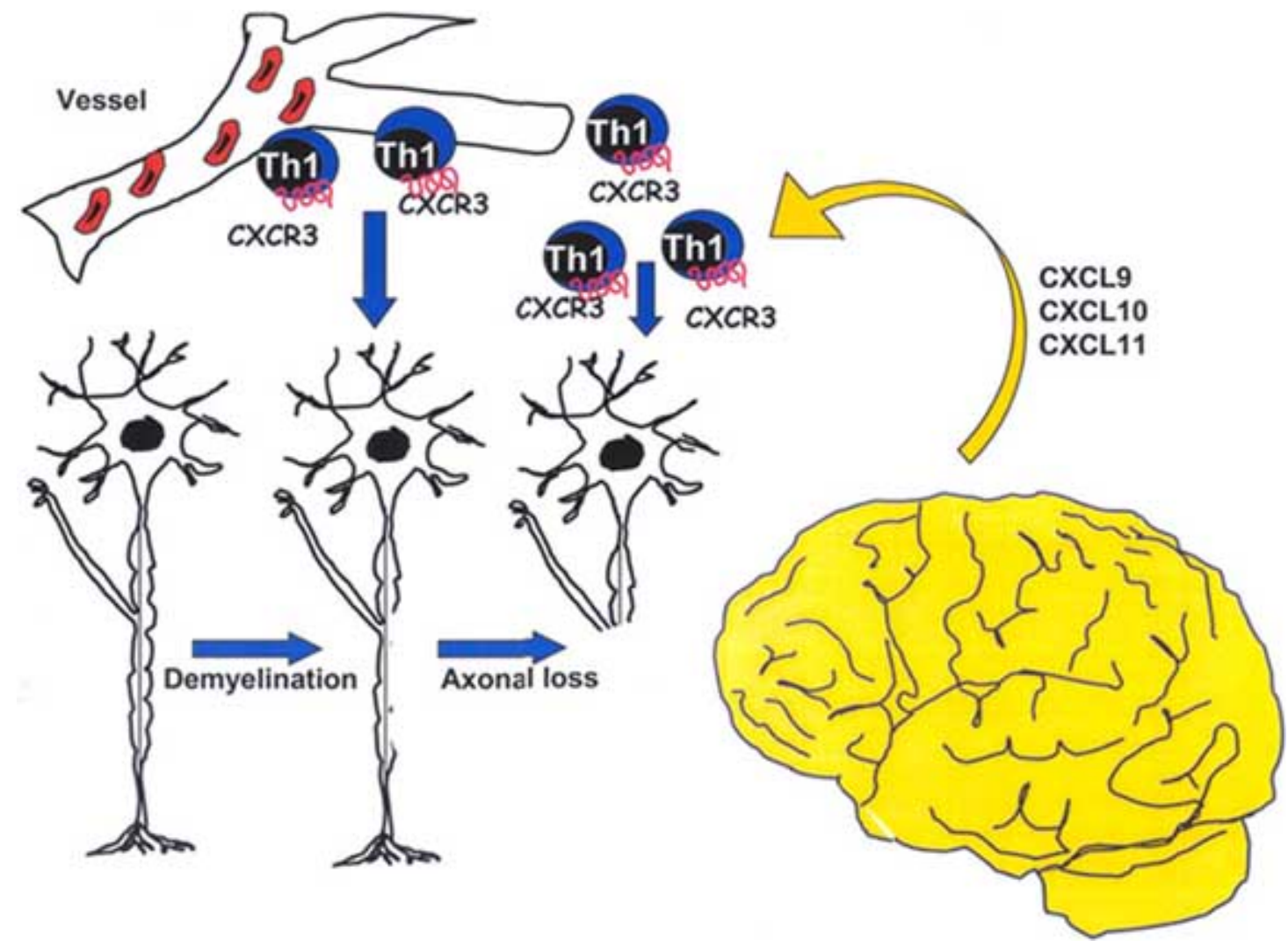

Fig. (2). Proposed mechanism of lymphocyte recruitment during the early phases of MS leading to demyelination. MS is an autoimmune disease associated with a T-helper type 1 phenotype. The recruitment of circulating auto-aggressive CXCR3 positive Th1 cells from peripheral vessels, leading to demyelination and then axonal loss, is mediated through brain production of CXCL9, CXCL10 and CXCL11. 
did not undergo CD95-induced apoptosis, due to the differential role of Th1 and Th2 cytokines. Indeed, IFN- $\gamma$ promoted caspase upregulation and CD95-induced apoptosis in HT thyrocytes, whereas IL-4 and IL-10 protected GD thyrocytes by potent up-regulation of cFLIP and Bcl- $\mathrm{X}_{\mathrm{L}}$, which prevented CD95-induced apoptosis in sensitized thyrocytes. Thus, modulation of apoptosis-related proteins by Th1 and Th2 cytokines control thyrocyte survival in thyroid autoimmune disorders [89]. Finally, the finding that the CXCR3-binding chemokines are not only produced by infiltrating $\mathrm{T}$ cells and macrophages, but also by resident follicular epithelial cells themselves, suggests that these latter may play a previously unrecognized role in the recruitment of infiltrating cells and therefore in the triggering of thyroid gland inflammation. However, the stimulatory agents (viral infections?) that may enable thyrocytes to produce CXCL10 and CXCL9 in the initial stages of autoimmune thyroid disorders are still unknown.

\section{CONCLUSIONS}

Since the discovery of the chemokine family the strategy of selectively blocking the leukocyte recruitment to the site of inflammation has been validated by several approaches. Indeed, despite redundancy reported by studies in vitro on ligand-receptor binding and activation, in vivo the system acts through a coordinated and perhaps sequential chain of events, with temporal and spatial control mechanisms coming into play. Thus, interfering with an essential link in the chain, such as CXCR3 in the case of some autoimmune disorders or organ allograft transplant or diabetes might result in a total inhibition of the inflammatory process, as demonstrated in CXCR3-/- models. Furthermore, the recent discovery of distinct receptors generated by alternative splicing of the CXCR3 gene would allow to obtain selective inhibitors of the two receptors, thus limiting undesired side effects. Otherwise a combined activation of the two receptors might be useful in some clinical conditions, such as cancer, where both enhancement of the immune response and inhibitory effects on angiogenesis and tumor cell growth are useful. We look forward to new types of experimental studies, since active orally available small molecule inhibitors of CXCR3 are now being developed.

\section{ACKNOWLEDGEMENTS}

We thank the Associazione Italiana per la Ricerca sul Cancro (A.I.R.C), the Ministero della Sanità and the Ministero per la Ricerca Scientifica for financial support to our studies.

\section{ABBREVIATIONS}

$\begin{array}{lll}\text { SDF-1 } & = & \text { Stromal-derived factor-1 } \\ \text { BRAK } & = & \text { Breast and kidney-expressed chemokine } \\ \text { SR-PSOX } & =\begin{array}{l}\text { Scavenger receptor that binds } \\ \text { phosphatidylserine and oxidized } \\ \text { lipoprotein }\end{array} \\ \text { IP-10 } & = & \text { IFN-inducible protein-10 }\end{array}$

\begin{tabular}{|c|c|c|}
\hline MIG & $=$ & $\begin{array}{l}\text { Monokine induced by interferon (IFN)- } \\
\text { gamma }\end{array}$ \\
\hline I-TAC & $=$ & $\begin{array}{l}\text { Interferon-inducible T-cell alpha } \\
\text { chemoattractant) }\end{array}$ \\
\hline $\mathrm{PF}-4$ & $=$ & Platelet factor four \\
\hline HMVEC & $=$ & Human microvascular endothelial cells \\
\hline Th1 & $=$ & Type-1 T helper cell \\
\hline NK & $=$ & Natural killer \\
\hline RACE & $=$ & Rapid amplification of cDNA ends \\
\hline HMEC-1 & $=$ & Human microvascular endothelial \\
\hline SCID & $=$ & Severe combined immunodeficiencies \\
\hline FGF-2 & $=$ & Fibroblast growth factor 2 \\
\hline VEGF165 & $=$ & Vascular endothelial growth factor \\
\hline AR & $=$ & Acute rejection \\
\hline $\mathrm{CR}$ & $=$ & Chronic rejection \\
\hline CsA & $=$ & Cyclosporine A \\
\hline$(\mathrm{IFN})-\gamma$ & $=$ & Interferon- $\gamma$ \\
\hline $\mathrm{mAbs}$ & $=$ & Monoclonal antibodies \\
\hline MCP-1 & $=$ & Monocyte chemoattractant protein 1 \\
\hline $\mathrm{EC}$ & $=$ & Endothelial cell \\
\hline SMC & $=$ & Smooth muscle cell \\
\hline CAV & $=$ & Chronic allograft vasculopathy \\
\hline GN & $=$ & Glomerulonephritis \\
\hline PGN & $=$ & Proliferative glomerulonephritis \\
\hline HMC & $=$ & Human mesangial cell \\
\hline TNF- $\alpha$ & $=$ & Tumor necrosis factor-alpha \\
\hline PDGF & $=$ & Platelet-derived growth factor \\
\hline EGF & $=$ & Epidermal growth factor \\
\hline IDDM & $=$ & $\begin{array}{l}\text { Insulin-dependent (type 1) diabetes } \\
\text { mellitus }\end{array}$ \\
\hline ICA & $=$ & Islet cell antibodies \\
\hline GAD & $=$ & Glutamic acid decarboxilase antibodies \\
\hline MS & $=$ & Multiple sclerosis \\
\hline CSF & $=$ & Cerebrospinal fluid \\
\hline MIP-1 $\alpha$ & $=$ & Macrophage inflammatory protein- $1 \alpha$ \\
\hline MIP-1ß & $=$ & Macrophage inflammatory protein-1 \\
\hline MCP-1 & $=$ & Monocyte chemoattractant protein 1 \\
\hline CNS & $=$ & Central nervous system \\
\hline GD & $=$ & Graves' disease \\
\hline HT & $=$ & Hashimoto's thyroidites \\
\hline TA & $=$ & Toxic adenoma \\
\hline
\end{tabular}

\section{REFERENCES}


[2] Rossi, D. and Zlotnik, A. (2000) Annu. Rev. Immunol., 18, 217-242.

[3] Godessart, N. and Kunkel, S.L. (2001) Curr. Opin. Immunol., 13(6), 670-675.

[4] Grone, H.J.; Cohen, C.D.; Grone, E.; Schmidt, C.; Kretzler, M.; Schlondorff, D. and Nelson. P.J. (2002) J. Am. Soc. Nephrol., 13(4), 957-967.

[5] Yoshie, O.; Imai, T.and Nomiyama, H. (2001) Adv. Immunol., 78, 57-110.

[6] Low, Q.E.; Drugea, I.A.; Duffner, L.A.; Quinn, D.G.; Cook, D.N.; Rollins, B.J.; Kovacs, E.J. and DiPietro, L.A. (2001) Am. J. Pathol., 159(2), 457-463.

[7] Belperio, J.A.; Keane, M.P.; Arenberg, D.A.; Addison, C.L.; Ehlert, J.E.; Burdick, M.D. and Strieter R.M.( 2000) J. Leukoc. Biol., 68(1), 1-8.

[8] Homey, B.; Müller, A. and Zlotnik, A. (2002) Nature Rev. Immunol., 2(3), 175-184.

[9] Romagnani, P.; Annunziato, F.; Lasagni, L.; Lazzeri, E.; Beltrame, C.; Francalanci, M.; Uguccioni, M.; Galli, G.; Cosmi, L.; Maurenzig, L.; Baggiolini, M.; Maggi, E.; Romagnani, S. and Serio, M. (2001) J. Clin. Invest. 107(1), 53-63.

[10] Salcedo, R.; Resau, J.H.; Halverson, D.; Hudson, E.A.; Dambach, M.; Powell, D.; Wasserman, K. and Oppenheim J.J. (2000) FASEB J., 14(13), 2055-2064.

[11] Luster, A.D.; Greenberg, S.M. and Leder, P. (1995) J. Exp. Med., 182(1), 219-31.

[12] Aronica, S.M.; Mantel, C.; Gonin, R.; Marshall, M.S.; Sarris, A.; Cooper, S.; Hague N.; Zhang, X.F. and Broxmeyer, H.E. (1995) J. Biol. Chem., 270(37), 21998-22007.

[13] Bonecchi, R.; Bianchi, G.; Bordignon, P.P.; D'Ambrosio, D.; Lang, R.; Borsetti, A.; Sozzani, S.; Allavena, P.; Gray, P.A.; Mantovani, A. and Sinigaglia, F. (1998) J. Exp. Med., 187(1), 129-134.

[14] Loetscher, M.; Gerber, B.; Loetscher, P.; Jones, S.A.; Piali, L.; Clark-Lewis, I.; Baggiolini, M. and Moser B. (1996) J. Exp. Med., 184(3), 963-969.

[15] Janatpour, M.J.; Hudak, S.; Sathe, M.; Sedgwick, J.D. and McEvoy, L.M. (2001) J. Exp. Med., 194(9), 1375-1384.

[16] Penna, G.; Sozzani, S. and Adorini, L. (2001) J. Immunol., 167(4), 1862-1866.

[17] Romagnani, P.; Annunziato, F.; Lazzeri, E.; Cosmi, L.; Beltrame, C.; Lasagni, L.; Galli, G.; Francalanci, M.; Manetti, R.; Marra, F.; Vanini, V.; Maggi, E. and Romagnani, S. (2001) Blood, 97(3), 601607.

[18] Deuel, T.F.; Senior, R.M.; Chang, D.; Griffin, G.L.; Heinrikson, R.L. and Kaiser, E.T. (1981) Proc. Natl. Acad. Sci. USA, 78(7), 4584-4587.

[19] Walz, A.; Dewald, B.; von Tscharner, V. and Baggiolini, M. (1989) J. Exp. Med.,170(5), 1745-1750.

[20] Romagnani, P.; Beltrame, C.; Annunziato, F.; Lasagni, L.; Luconi, M.; Galli, G.; Cosmi, L.; Maggi, E.; Salvadori, M.; Pupilli, C. and Serio, M. (1999) J. Am. Soc. Nephrol., 10(12), 2518-2526.

[21] Bonacchi, A.; Romagnani, P.; Romanelli, R.G.; Efsen, E.; Annunziato, F.; Lasagni, L.; Francalanci, M.; Serio, M.; Laffi, G.; Pinzani, M.; Gentilini, P. and Marra, F. (2001) J. Biol. Chem., 276(13), 9945-9954

[22] Wang, X.; Lue, T.L.; Ohlstein, E.H.; Sung, C.P.; Fuerstein, G.Z. (1996) J. Biol. Chem., 271(39), 24286-24293.

[23] Lasagni, L.; Francalanci, M.; Annunziato, F.; Lazzeri, E.; Giannini, S.; Sagrinati, C.; Mazzinghi, B.; Cosmi, L.; Orlando, C.; Marra, F.; Maggi, E.; Romagnani, S.; Serio, M. and Romagnani, P. (2003) J. Exp. Med., 197(11), 1537-1549.

[24] Luster, A.D.; Leder, P. (1993) J. Exp. Med., 178(3), 1057-1065.

[25] Arenberg, D.A.; Kunkel, S.L.; Polverini, P.J.; Morris, S.B. ; Burdick, M.D. ; Glass, M.C. ; Taub, D.T. ; Iannettoni, M.D. ; Whyte, R.I. and Strieter, R.M. (1996) J. Exp. Med., 184(3), 981992.

[26] Arenberg, D.A.; White, E.S.; Burdick, M.D.; Strom, S.R. and Strieter, R.M. (2001) Cancer Immunol. Immunother., 50(10), 533538 .

[27] Sgadari, C.; Angiolillo, A.L.; Cherney, B.W.; Pike, S.E.; Farber, J.M.; Koniaris, L.G.; Vanguri, P.; Burd, P.R.; Sheikh, N.; Gupta, G.; Teruya-Feldstein, J. and Tosato, G. (1996) Proc. Natl. Acad. Sci. USA, 93(24), 13791-13796.

[28] Addison, C.L.; Arenberg, D.A.; Morris, S.B.; Xue, Y.Y.; Burdick, M.D.; Mulligan, M.S.; Iannettoni, M.D. and Strieter, R.M. (2000) Hum. Gene Ther., 11(2), 247-261.
[29] Sgadari, C.; Farber, J.M.; Angiolillo, A.L.; Liao, F.; TeruyaFeldstein, J.; Burd, P.R.; Yao, L.; Gupta, G.; Kanegane, C. and Tosato, G. (1997) Blood, 89(8), 2635-2643.

[30] Yao, L.; Sgadari, C.; Furuke, K.; Bloom, E.T.; Teruya-Feldstein, J. and Tosato, G. (1999) Blood, 93(5), 1612-1621.

[31] Tannenbaum, C.S.; Tubbs, R.; Armstrong, D.; Finke, J.H.; Bukowski, R.M. and Hamilton, T.A. (1998) J. Immunol., 161(2), 927-932.

[32] Pertl, U.; Luster, A.D.; Varki, N.M.; Homann, D.; Gaedicke, G.; Reisfeld, R.A. and Lode, H.N. (2001) J. Immunol., 166(11), 69446951.

[33] Kanegane, C.; Sgadari, C.; Kanegane, H.; Teruya-Feldstein, J.; Yao, L.; Gupta, G.; Farber, J.M.; Liao, F.; Liu, L. and Tosato, G. (1998) J. Leukoc. Biol., 64(3), 384-392.

[34] Sgadari, C.; Angiolillo, A.L. and Tosato, G. (1996) Blood, 87(9), 3877-3882.

[35] Sharpe, R.J.; Byers, H.R.; Scott, C.F.; Bauer, S.I. and Maione, T.E. (1990) J. Natl. Cancer Inst., 82(10), 848-853.

[36] Hampl, M.; Tanaka, T.; Albert, P.S.; Lee, J.; Ferrari, N. and Fine, H.A. (2001) Hum. Gene Ther., 12(14), 1713-1729.

[37] Tanaka, T.; Manome, Y.; Wen, P.; Kufe, D.W. and Fine, H.A. (1997) Nat. Med., 3(4), 437-442.

[38] Kolber, D.L.; Knisely, T.L. and Maione, T.E. (1995) J. Natl. Cancer Inst., 87(4), 304-309.

[39] Maione, T.E.; Gray, G.S.; Hunt, A.J. and Sharpe, R.J. (1991) Cancer Res., 51(8), 2077-2083.

[40] Giussani, C.; Carrabba, G.; Pluderi, M.; Lucini, V.; Pannacci, M. Caronzolo, D.; Costa, F.; Minotti, M.; Tomei, G.; Villani, R.; Carroll, R.S.; Bikfalvi, A. and Bello, L. (2003) Cancer Res., 63(10), 2499-2505.

[41] Perollet, C.; Han, Z.C.; Savona, C.; Caen, J.P. and Bikfalvi, A. (1998) Blood, 91(9), 3289-3299.

[42] Gengrinovitch, S.; Greenberg, S.M.; Cohen, T.; Gitay-Goren, H.; Rockwell, P.; Maione, T.E.; Levi, B.Z. and Neufeld, G. (1995) J. Biol. Chem., 270(25), 15059-15065.

[43] Hansell, P.; Olofsson, M.; Maione, T.E.; Arfors, K.E. and Borgstrom, P. (1995) Acta Physiol. Scand., 154(4), 449-459.

[44] Borgstrom, P.; Discipio, R. and Maione, T.E. (1998) Anticancer Res., 18(6A), 4035-4041.

[45] Hansell, P.; Maione, T.E. and Borgstrom, P. (1995) Am. J. Physiol., 269(3 Pt 2), H829-836.

[46] Wang, Y.Q.; Wada, A.; Ugai, S. and Tagawa, M. (2003) Oncol. Rep., 10(4), 909-913.

[47] Tatakis, D.N. (1992) Biochem. Biophys. Res. Commun., 187(1), 287-293.

[48] Kahan, B.D. and Ponticelli, C. (editors). (2000) Principles and Practice in renal transplantation. London. Martin Dunitz Ltd, 846 pp.

[49] Hancock, W.W.; Lu, B.; Gao, W.; Csizmadia, V.; Faia, K.; King, J.A.; Smiley, S.T.; Ling, M.; Gerard, N.P. and Gerard, C. (2000) J. Exp. Med., 192(10), 1515-1520.

[50] Hancock, W.W.; Gao, W.; Csizmadia, V.; Faia, K.L.; Shemmeri, N. and Luster, A.D. (2001) J. Exp. Med., 193(8), 975-980.

[51] Zhang, Z.; Kaptanoglu, L.; Haddad, W.; Ivancic, D.; Alnadjim, Z.; Hurst, S.; Tishler, D.; Luster, A.D.; Barrett, T.A. and Fryer J. (2002) J. Immunol., 168(7), 3205-3212.

[52] Jiankuo, M.; Xingbing, W.; Baojun, H.; Xiongwin, W.; Zhuoya, L.; Ping, X.; Yong, X.; Anting, L.; Chunsong, H.; Feili, G. and Jinquan, T. (2003) J. Immunol., 170, 1556-1565.

[53] Fernandez-Botran, R.; Gorantla, V.; Sun, X.; Ren, X.; PerezAbadia, G.; Crespo, F.A.; Oliver, R.; Orhun, H.I.; Quan, E.E.; Maldonado C.; Ray M. and Barker J.H. (2002) Transplantation, 74(5) 623-629.

[54] Melter, M.; Exeni, A. and Briscoe, D.M. (2002) Curr. Opin. Organ Transplantation, 7, 77-84

[55] Segerer, S.; Cui, Y.; Eitner, F.; Goodpaster, T.; Hudkins, K.L.; Mack, M.; Cartron, J.P.; Colin, Y.; Schlondorff, D. and Alpers, C.E. (2001) Am. J. Kidney Dis., 37(3), 518-531.

[56] Agostini, C.; Calabrese, F.; Rea, F.; Facco, M.; Tosoni A.; Loy, M.; Binotto, G.; Valente, M.; Trentin, L. and Semenzato, G. (2001) Am. J. Pathol., 158(5), 1703-1711.

[57] Melter, M.; Exeni, A.; Reinders, M.E.; Fang, J.C.; McMahon, G.; Ganz P.; Hancock, W.W. and Briscoe, D.M. (2001) Circulation, 104(21), 2558-2564 
[58] Zhao, D.X.; Hu, Y.Y.; Miller, G.G.; Luster, A.D.; Mitchell R.N. and Libby, P. (2002) J. Immunol., 169(3), 1556-1560.

[59] Fahmy, N.M.; Yamani, M.H.; Starling, R.C.; Ratliff, N.B.; Young, J.B.; McCarthy, P.M.; Feng, J.; Novick, A.C. and Fairchild, R.L. (2003) Transplantation, 75(1), 72-78.

[60] Kao, J.; Kobashigawa, J.; Fishbein, M.C.; MacLellan, W.R.; Burdick, M.D.; Belperio, J.A. and Strieter, R.M. (2003) Circulation, 107(15), 1958-1961.

[61] Beaudeux, J.L.; Dorent, R.; Bernard, M.; Reagan, M.; Foglietti, M.J.; Gandjbakhch, I. and Cacoub, P. (2002) Clin. Biochem., 35(1), 77-79.

[62] Galla, J,H. (1995) Kidney Int., 47(2), 377-387.

[63] Abboud, H.E. (1992) J. Am. Soc. Nephrol., 2(Suppl. 10): S185-189.

[64] Sedor, J.R.; Konieczkowski, M.; Huang, S.; Gronic, J.H.; Nakazato, Y.; Gordon, G. and King, C.H. (1993) Kidney Int., 39, S65-S70.

[65] Gomez-Chiarri, M.; Ortiz, A.; Gonzalez-Cuadrado, S.; Seron, D.; Emancipator, S.N.; Hamilton, T.A.; Barat, A.; Plaza, J.J.; Gonzalez, E. and Egido, J. (1996) Am. J. Pathol., 148(1), 301-311.

[66] Romagnani, P.; Lazzeri, E.; Lasagni, L.; Mavilia, C.; Beltrame, C.; Francalanci, M.; Rotondi, M.; Annunziato, F.; Maurenzig, L.; Cosmi, L.; Galli, G.; Salvatori, M.; Maggi, E. and Serio, M. (2002) J. Am. Soc. Nephrol., 13(1), 53-64.

[67] Lim, C.S.; Zheng, S.; Kim, Y.S.; Ahn, C.; Han, J.S.; Kim, S.; Lee, J.S.; Chae, D.W.; Koo, J.R.; Chun, R.W. and Noh, J.W. (2001) Nephrol. Dial. Transplant, 16(2), 269-275.

[68] Marra, F.; Choudhury, G.G. and Abboud, H.E. (1996) J. Clin. Invest., 98(5), 1218-1230z.

[69] Frigerio, S.; Junt, T.; Lu, B.; Gerard, C.; Zumsteg, U.; Hollander, G.A. and Piali, L. (2002) Nat. Med., 8(12), 1414-1420.

[70] Rotondi, M.; Lazzeri, E.; Romagnani, P. and Serio, M. (2003) J. Endocrinol. Invest., 26(2), 177-180.

[71] Hanifi-Moghaddam, P.; Schloot, N.C.; Kappler, S.; Seissler, J. and Kolb, H. (2003) Diabetes, 52(5), 1137-1142.

[72] Shimada, A.; Morimoto, J.; Kodama, K.; Suzuki, R.; Oikawa, Y.; Funae, O.; Kasuga, A.; Saruta, T. and Narumi, S. (2001) Diabetes Care, 24(3), 510-515.

[73] Nicoletti, F.; Conget, I.; Di Mauro, M.; Di Marco, R.; Mazzarino, M.C.; Bendtzen, K.; Messina, A. and Gomis, R. (2002) Diabetologia, 45(8), 1107-1110.

[74] Rotondi, M.; Romagnani, P.; Brozzetti, A.; Santeusanio, F.; Serio, M. and Falorni, A. (2003) Diabetologia, 46(7), 1020-1021.
[75] Romagnani, P.; Rotondi, M.; Lazzeri, E.; Lasagni, L.; Francalanci, M.; Buonamano, A.; Dilani, S.; Vitti, P.; Chiovato, L.; Tonacchera, M.; Bellastella, A. and Serio M. (2002) Am. J. Pathol., 161(1), 195206.

[76] Sorensen, T.L.; Trebst, C.; Kivisakk, P.; Klaege, K.L.; Majmudar, A.; Ravid, R.; Lassmann, H.; Olsen, D.B.; Strieter, R.M.; Ransohoff, R.M. and Sellebjerg, F. (2002) J. Neuroimmunol., 127(1-2), 59-68.

[77] Balashov, K.E.; Rottman, J.B.; Weiner, H.L. and Hancock, W.W. (1999) Proc. Natl. Acad. Sci. USA, 96(12), 6873-6878.

[78] Sorensen, T.L.; Tani, M.; Jensen, J.; Pierce, V.; Lucchinetti, C.; Folcik, V.A.; Qin, S.; Rottman, J.; Sellebjerg, F.; Strieter, R.M.; Frederiksen, J.L. and Ransohoff, R.M. (1999) J. Clin. Invest., 103(6), 807-815.

[79] Lahrtz, F.; Piali, L.; Nadal, D.; Pfister, H.W.; Spanaus, K.S.; Maggiolini, M. and Fontana, A. (1997) Eur. J. Immunol., 27(10), 2484-2489.

[80] Biddison, W.E.; Cruikshank, W.W.; Center, D.M.; Pelfrey, C.M.; Taub, D.D. and Turner, R.V. (1998) J. Immunol., 160(1), 444-448.

[81] Kemp, E.H.; Metcalfe, R.A.; Smith, K.A.; Woodroofe, M.N.; Watson, P.F. and Weetman, A.P. (2003) Clin. Endocrinol., (Oxf) 59(2), 207-213.

[82] Mariotti, S.; del Prete, G.F.; Mastromauro, C.; de Carli, M.; Romagnani, S.; Ricci, M. and Pinchera, A. (1991) Exp. Clin. Endocrinol., 97(2-3), 139-146.

[83] Garcia-Lopez, M.A.; Sancho, D.; Sanchez-Madrid, F. and Marazuela, M. (2001) J. Clin. Endocrinol. Metab., 86(10), 50085016.

[84] Scarpino, S.; Stoppacciaro, A.; Ballerini, F.; Marchesi, M.; Prat, M.; Stella, M.C.; Sozzoni, S.; Allavena, P.; Mantovani, A. and Ruco, L.P. (2000) Am. J. Pathol., 156(3), 831-837.

[85] Aniszewski, J.P.; Valyasevi, R.W. and Bahn, R.S. (2000) J. Clin. Endocrinol. Metab., 85(2), 776-780.

[86] Delgado, M.; Abad, C.; Martinez, C.; Leceta, J. and Gomariz, R.P. (2001) Nat. Med., 7(5), 563-568.

[87] Miyamoto, K.; Miyake, S. and Yamamura, T. (2001) Nature, 413(6885), 531-534.

[88] Stassi, G.; Di Liberto, D.; Todaro, M.; Zeuner, A.; Ricci-Vitiani, L.; Stoppacciaro, A.; Ruco, L.; Farina, F.; Zummo, G. and De Maria, R. (2000) Nat. Immunol., 1(6), 483-488.

[89] Stassi, G. and De Maria, R. (2002) Nat. Rev. Immunol., 2(3), 195204. 
Copyright of Current Drug Targets - Immune, Endocrine \& Metabolic Disorders is the property of Bentham Science Publishers Ltd. and its content may not be copied or emailed to multiple sites or posted to a listserv without the copyright holder's express written permission. However, users may print, download, or email articles for individual use. 